\title{
EVALUATION OF THE MANAGEMENT OF BROWN HARE POPULATION IN VOJVODINA REGION FOR THE PERIOD 1967-2011
}

\author{
Zoran A. Ristić ${ }^{1}$, Igor Ponjiger ${ }^{1}$, Vladimir Mijailović ${ }^{2}$, \\ Vasilije Tešić ${ }^{1}$, Milutin Kovačević ${ }^{1}$, Milosava Matejević ${ }^{1}$, \\ Petar Padejski ${ }^{1}$, Vladimir Marković ${ }^{1}$, Dajana Lulić ${ }^{1}$ \\ ${ }^{1}$ Faculty of Science, University of Novi Sad, Novi Sad \\ ${ }^{2}$ Poljoprivredni kombinat Beograd, Padinska Skela, Beograd
}

\section{Abstract}

Every year during the past 45 years (1967-2011), hunting organizations have been sending eye lenses (lens cristallina) to the Laboratory for hunting of the hunting association of Vojvodina for testing and analysis of the percentage of young hares in a micro population to establish the real growth rate. These two parameters combined with the number of hares in spring and cull rate from last year were sufficient to provide hunting organizations with precise information about hunting dynamics and rate of hunting in current hunting season. At the beginning, (in 1967), only $20 \%$ of hunting organizations submitted the samples, but ten years after the first sample had been collected, the percentage has gradually increased to $30 \%$ in 1977 Since then, the percentage of hunting organizations that were sending samples increased to $45 \%$ in $1987,60 \%$ in 1997 , and $70 \%$ in 2007 with a maximum of $77 \%$ percentage in 2008 . Throughout the research period of 45 years, the total number of examined and processed eye lenses was 363,380 . Out of 8,727 samples approximately 8,075 eye lenses were processed yearly. A small number of hunting organizations which didn't send any samples haven't been hunting brown hare in their hunting grounds during these years. During this research, several conclusions were made: the percentage of young hares in populations varies from 38\% in 2010 to $70.3 \%$ in 1994. The average percentage for period of 45 years was $58.4 \%$ of young hares in a population. According to the research, the coefficient of real growth was 1.58 young hare per female hare. The minimum was 1.13 in 2010 , and the maximum was 2.33 in 1994 . These analyses provided the actual information

\footnotetext{
${ }^{1}$ Corresponding author: balzakova@yahoo.com
} 
about stability and health of hare populations and enable a sustainable longterm planning of these game species.

Key words: brown hare, Lepus europaeus Pallas, game management, real growth rate

\title{
GAZDOVANJE POPULACIJOM ZECA U VOJVODINI ZA PERIOD OD 1967. DO 2011. GODINE
}

\author{
Zoran A. Ristić ${ }^{1}$, Igor Ponjiger ${ }^{1}$, Vladimir Mijailović ${ }^{2}$, \\ Vasilije Tešić ${ }^{1}$, Milutin Kovačević ${ }^{1}$, Milosava Matejević ${ }^{1}$, \\ Petar Padejski ${ }^{1}$, Vladimir Marković ${ }^{1}$, Dajana Lulić ${ }^{1}$ \\ ${ }^{1}$ Prirodno-matematički fakultet, Univerzitet u Novom Sadu, Novi Sad \\ ${ }^{2}$ Poljoprivredni kombinat Beograd, Padinska Skela, Beograd
}

\section{Kratak sadržaj}

U proteklom periodu od 45 godina (1967-2011), u Laboratoriju za lovstvo Lovačkog saveza Vojvodine lovačke organizacije su neprekidno svake godine slale očna sočiva (lens cristallina) radi utvrđivanja, učešća mladih u mikropopulaciji, i na osnovu toga realnog prirasta. Ova dva parametra su, zajedno sa prolećnim brojnim stanjem i odstrelom u prethodnoj godini, bila dovoljna da im Stručna služba Saveza da preporuku kako i koliko treba da love u tekućoj lovnoj godini. U početku (1967. godine) je oko $20 \%$ lovačkih udruženja slalo uzorke, da bi nakon 10 godina (1977.) to iznosilo preko $30 \%$, 1987. godine preko 45\%, 1997. godine preko 60\% i 2007. godine oko $70 \%$, sa maksimumom zabeleženim u 2008. godini od skoro $77 \%$. Za period od 45 godina pregledano je ukupno 363.380 očiju ulovljenih zečeva, što prosečno godišnje iznosi 8.075 očnih sočiva iz 8.727 uzoraka. Manji broj lovišta koji nije slao uzorke nije ni lovio zeca tih godina. Istraživanjima je utvrđeno da je za ovako dugi period prosečan procenat mladih je bio 58,4\% (sa minimumom od 38,0\% zabeleženim 2010. godine i maksimumom od $70,3 \%$ zabeleženim 1994. godine), odnosno da je prosečan koeficijenat realnog prirasta bio 1,58 zečića po zečici (sa minimumom od 1,13 zabeleženim 2010. godine i maksimumom od 2,33 zabeleženim 1994. godine). Ovakve analize omogućuju najbolji način za praćenje populacije, kao i plansko i dugoročno održivo gazdovanje.

Ključne reči: zec, Lepus europaeus Pallas, gazdovanje, realni prirast 


\section{INTRODUCTION}

The actual age of hare (Lepus europeus Pallas, 1778) can be determined in several ways. One method is currently used for scientific purposes in Vojvodina and hunting organizations plan their hunting quotas according to the annual growth rate for micro populations of brown hare.

With more than 45 years of experience, since 1967, the annual growth rate is determined in October, after the first few hare hunting days. At the beginning, from 1967 to 1987, the analyses were conducted at the Faculty of Agriculture of Novi Sad. Since 1987, the research were conducted in the laboratory for hunting at the Hunting Association of Vojvodina. The minimum number of eye samples required to be submitted for examination is 30. After submission, in the controlled laboratory conditions, the research is conducted and eye lenses are processed. Subsequently, the hunting laboratory issues a recommendation for further hunting in the specific hunting ground. After collecting information about annual grow rate, spring counting of hares in hunting grounds, and number of hares hunted in the first few hunts it is easy to give advice and plan the dynamics of the cull in each hunting organization.

If the analyses reveal the share of young is less than $50 \%$ it is very important to stop further hunting. Although this method is in use in different countries (Hungary, Check Republic), its highest application is recorded in Vojvodina region.

The research of Valentinčić (1956) on the ideal annual grow rate was performed at one hunting ground in Vojvodina (study area - island "Biserno") in 1954 and 1955. The results of this research showed that brown hares have 5 litters per year in this region of Vojvodina.

The first litter appears in March (8 - 25), with a peak from 18-20 March. That means, the main mating season starts on $25^{\text {th }}$ of January and lasts till $11^{\text {th }}$ of February, with a peak around $5^{\text {th }}$ of February. This data pertained to year 1954, but in 1955, the litters were found from the 1-20 March with a peak around 10-15 of March. Thus, we can conclude that the prime mating season started on 17 January and lasted up to 5 February, with highest mating activity from 27 January until 1 February. In the first litter, during these two years of research, the number of young hares per female was 1.23. The second litter in 1954 appeared in the period 25 April - 5 May. That means that the second mating season for hares was in March, i.e., from 15 to 25 March. For a two-year research period, the average number of small hares per litter was 2.9 per year. The third litter was born from 5 to 23 June with a peak on 5 June. Thus, the third mating season was between 23 April and 15 May with a peak on 5 May. 
In the third litter, the number of young hares was 2.75 per female. In the fourth litter, small hares were born in the period from the end of July until 10 August, peaking on 5 August. Hares were mating in June $(20-30)$, and the number of the young per litter was 1.2. The fifth litter of hares was born between 5 and 20 September with a peak on 12 September. The mating season started on 25 July and ended by 10 August with a peak on the 1 August.

According to the research results we can conclude that of the majority of females gave birth five times a year, and the first litter can be found from $10-20$ March, second from 25-30 April, third from 1-15 June, fourth litter is born from 1 to 15 August, and the fifth litter can be found between $12-25$ September.

The second and third litters are major litters in the year; if they are successful, it is very likely that hare population will be plentiful in this year. These hares are born between end of April and middle of June, thus, the hunters must be highly concerned and put maximum efforts to preserve this precious game. It is very interesting that during this research, there wasn't a single female that gave birth in the same year when she was born.

Analyzing data for three years (1974-1976) Jovanović and Aleksić (1976) have concluded the following: 1) In the first litter, 57\% females were fecundated and had 0.6 fetus after the cull in autumn; 2) In the second litter, $88 \%$ females were fecundated and had 2.5 fetus in uterus; 3 ) In the third litter, $92 \%$ females were fecundated and had 3.9 fetus in uterus; 4) In the fourth litter, 100 $\%$ females were fecundated after the cull and had 3.4 fetuses in uterus; and 5) In the fifth litter, $46 \%$ females were fecundated after the cull and they had averagely 1.2 fetuses.

At the conclusion of this research, it was apparent that $79 \%$ of hunted female hares were fecundated. Valentinčić (Valentinčić, 1955) established that the percentage of fecundated females was $68 \%$ in 1954 and 1955, while the number of fetuses in uterus was 1.5. However, the research from 1976 revealed that percentage of fetus was higher, being 2.4.

Valentincić established that the most numerous litters were second and third (3.3 and 2.5), and Aleksić and Jovanović concluded that the most numerous litters were third and fourth (3.9 and 3.4).

There is a range of methods for determination of the age of hares. Some can be performed in the field, do not require any specific equipment and are easy to learn and to perform. The methods that do not require particular scientific knowledge and laboratory equipment include measuring the body mass of hare, assessment how easily ears are torn, forehead color, and tear bone These methods are not always accurate but they are easy and fast, so we use them to make some rough estimation of the age of hunted hares. 
Lord (Lord, 1959) found a new and scientifically based method to determine the age of hares. He did his experiment on a hare from Florida (Sylvilagus floridanus). The experiment was based on the data reported by English ophthalmologist Smith (Smith, 1883), who found that eye pupil and its elements is the only part of hare's body that never stops growing. Lord experimented with 92 hares with known age. His experiment was totally functional and was a great scientific discovery. Nowadays, thanks to him, the age of hares and hares can be estimated with a month-level precision. In European terminology, the method is known as Rieck method (Rieck, 1962) as he was the first one who applied it on brown hare (Lepus europaeus Pallas).

The most accurate measurements and experiments on brown hare were conducted by Cabon-Raczynski and Raczynski (Cabon-Raczynski, Raczynski, 1972) on a sample of 2,277 hares. They were measuring the mass of dried eye lenses and established the borderline values for young hare and older ones. The borderline value is $275 \mathrm{mg}$, that is, the mass below this value indicates that the hare is young, while lenses of bigger weight belong to older hares.

Another method for determination of hare age is that of Strahov (Stroch, 1931), which is based on capture re-capture method; however, is not that accurate and it differs for some $20 \%$ from the method of dried eye lenses. The authors who applied this method were Andersen and Jensen (Andersen, Jensen, 1972). The method is still in use, but it is far more unreliable than the Lord method (Lord, 1956).

Several other researchers used the method of dry eye lenticular weight for determining of age not only of hares but also some other game species. Some authors examined the influence of different methods of fixation and drying of eye lenses on the precision of results. Andersen and Jensen (Andersen, Jensen, 1972) recommend the drying at $60^{\circ} \mathrm{C}$ to obtain the best results, whereas Černe (1976) recommends the drying temperature of $110^{\circ} \mathrm{C}$.

\section{MATERIAL AND METHODS}

\section{Brown hare age determination based on the weight of eye lenses}

In the Laboratory for Hunting of the Faculty of Agriculture in Novi Sad, the method of determining the age of hares has been used since 1967. The process of fixing and processing of the material is done by carefully pulling the eyeball of the harvested hares, which is then placed in a $5-10 \%$ solution of formalin (formaldehyde), and left there for 3-4 days. Then, the lens is removed and dried for 72 hours at $55-60^{\circ} \mathrm{C}$ in the thermostat. Once completely dry, they lenses are weighed on Mettler scale with an accuracy of $5 \mathrm{mg}$. Uniformity of 
the preparation, drying and measurement of the lenses from the beginning of this method is guaranteed by the laboratory and offers the possibility of comparing the results from different years. The resulting data have already been used to determine the real hunting quota of hares, as well as active measures to protect the hare population in Vojvodina (Šelmić, 1977).

Based on the weight when dry, the population was categorized into six age classes.

I age class, of up to $100 \mathrm{mg}$ - hares up to 3 months

II age class, of 100 to $200 \mathrm{mg}$ - hares aged 3- 6 months

III age class, of 200 to $280 \mathrm{mg}$ - hares aged $6-12$ months

IV age class, from 280 to $310 \mathrm{mg}$ - hares aged 1 to 2 years

$\mathrm{V}$ age class, of 310 to $370 \mathrm{mg}$ - hares aged 3-4 years

VI age class, over $370 \mathrm{mg}$ - hares over 4 years of age

Values between age classes were determined on the basis of research by Andersen and Jensen (Andersen, Jensen, 1972) and the criteria of Miller (Möller, 1975) and Šelmić (Šelmić, 1977). This type of research in Vojvodina has continuously been done for 45 years (1967-2011), and 363,380 lenses from 7,873 samples have been processed and measured so far.

\section{Calculating growth rate based on the share of young}

As aforementioned, this type of research has been performed in Vojvodina for over 40 years, and up to now, the method has given excellent results. Thanks to this research annual hunting bag is carefully and sustainably planned.

Based on the established share of young hares in the population (up to one year old) at the beginning of hunting season and criteria for evaluation of real growth (Šelmić, 1977) as well as data obtained from hunting associations on the numerical strength of the spring population and the hunting bag from that year, expert service is able to make a recommendation on hunting possibilities. The proposal to reduce hunting quotas refers mostly to those hunting organizations, in which the participation of young hares in a total population is less than $50 \%$. 
Table 1. Growth assessment based on the number of young hares in the population

\begin{tabular}{|c|c|c|}
\hline $\begin{array}{c}\text { Growth } \\
\text { assessment }\end{array}$ & $\begin{array}{c}\text { Share of young hares } \\
\text { in the population }\end{array}$ & $\begin{array}{c}\text { Periodic real growth } \\
\text { rate in relation to the } \\
\text { spring population }\end{array}$ \\
\hline Very low & Up to $40 \%$ & Up to $20 \%$ \\
\hline Low & from $41 \%-50 \%$ & $21 \%-40 \%$ \\
\hline Good & from $51 \%-57 \%$ & $41 \%-62 \%$ \\
\hline Very good & from $58 \%-63 \%$ & $63 \%-90 \%$ \\
\hline Great & over $64 \%$ & over $90 \%$ \\
\hline
\end{tabular}

The growth of the population of hares depends on a number of environmental factors, modern machinery, the use of pesticides in the hunting ground, increased number of predators and other; therefore, these studies have so far proved valuable because they preserved the population stable.

\section{RESULTS AND DISCUSSION}

The coefficient of real growth until the hunting season, calculated on the basis of the share of young hares in the population at the beginning of the hunt, shows a balanced flow for the entire observed period. Two extremes were recorded in 1993 (2.26) and 1994 (2.33), thus ending up with highest real growth rate in 42 years since this method is applied in practice (Graph 2).

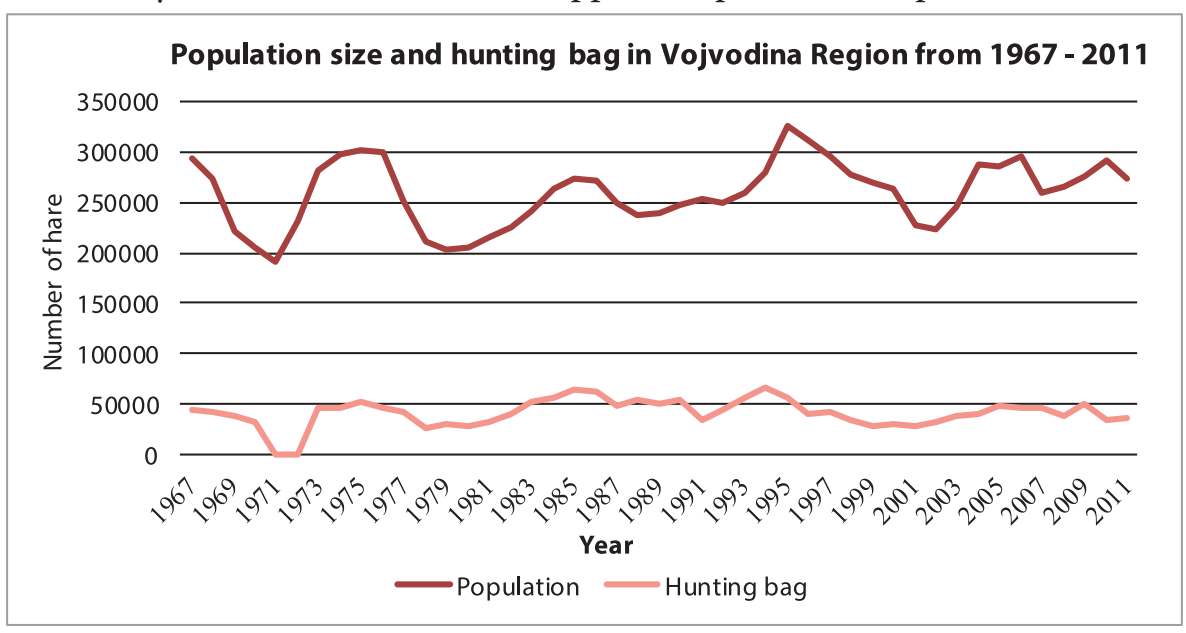

Graph 1. Population and annual hunting bag of hare (Lepus europaeus Pall.) for 1967-2011 period 
Quantity of hare population in Vojvodina (Graph 1) in the observed period was balanced except in 1971 when the least number of hares was recorded. Consequently, two-year ban on hare hunting was imposed (1971 and 1972), except for experimental purposes (Vapa et al, 2007).

Hunting bag in the same period ranged mostly between 35,000 and 45,000 (Graph 1), with the overall average being 43,033. The highest annual hunting bag was recorded in $1985(63,591)$ and $1994(65,848)$. The highest percentage of use was recorded in 1985 (23.3\%) and 1986 (22.7\%), with the average value for the entire period being $16.63 \%$. The percentage of use was the lowest in 1999 remaining at $10.1 \%$. In the 1990s, throughout entire Vojvodina region, partial ban on hunting was imposed because of war. Share of young hares in the population (Graph 2) at the beginning of the hunting season and calculated real growth rate (Graph 3) show balanced flow in the observed period. Lowest share of young hares was recorded in 1975 (47.3\%) and 2010 (38.0\%), with the average for the entire observed period being $58.4 \%$.

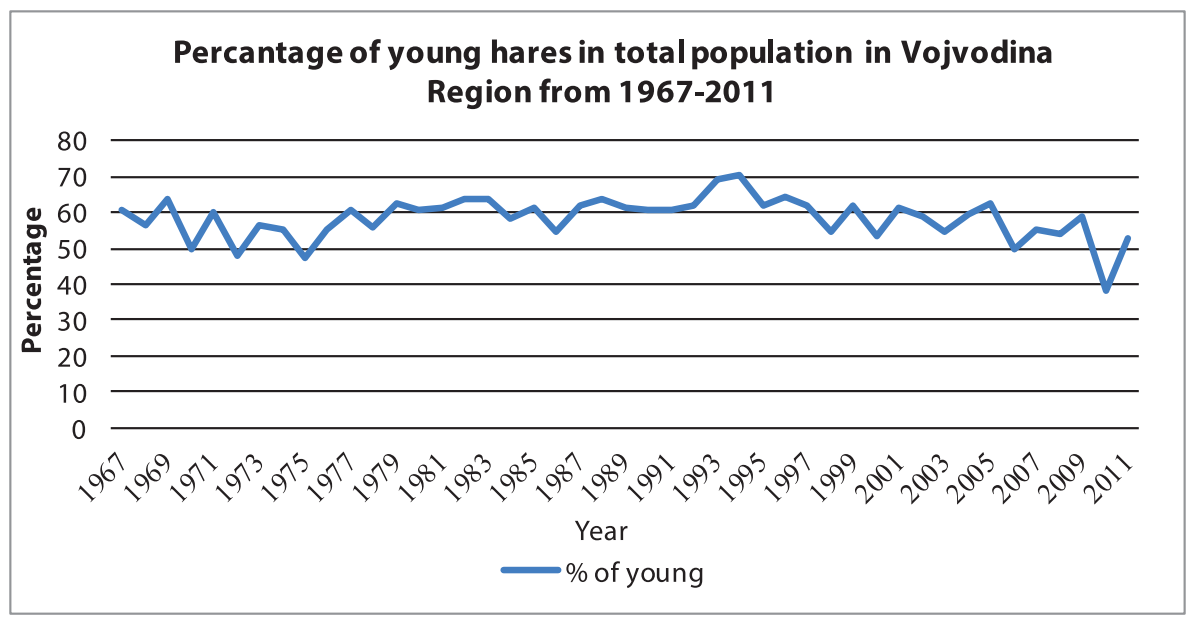

Graph 2. Share of young hares in the population for the period 1967-2011

Real growth coefficient (Graph 3) was the lowest in 1972 (1.25), when hunting was banned and in 2010 being only 1.13 . The maximum coefficient of real growth was recorded in 1993 (2.28) and 1994 (2.33), with an average for the entire observed period being 1.58 . 


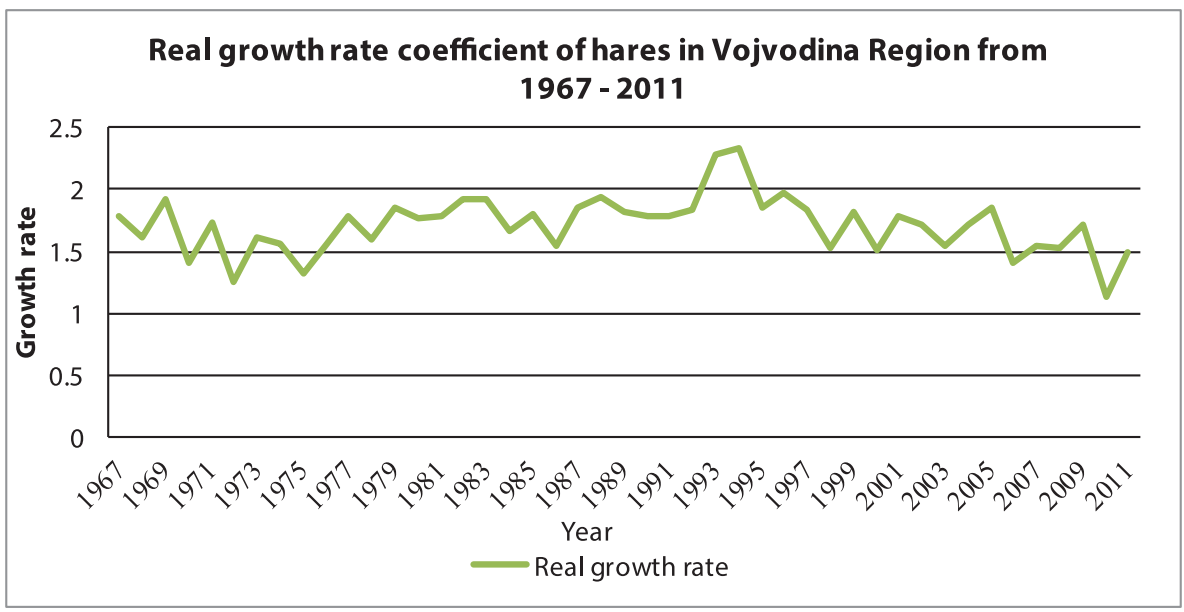

Graph 3. Real growth coefficient of hares for the period 1967-2011

\section{CONCLUSION}

Determining the real annual growth of hares is of an invaluable importance for an effective evaluation of hare population. Using data on the spring population number and winter losses, an overall assessment can be made in order to preserving the hare population in our country.

When preparing relevant documents and planning hare population dynamics, it is recommended to apply the average real growth coefficient of 1.58 calculated on the basis of the average values for several decades. Using a higher coefficient than calculated could quickly result in the reduction in the number of hares in the hunting area, and consequent unrealistic harvest.

The method for determining the share of young hares in the population in Vojvodina, and subsequently calculated real growth was fully accepted by hunting organizations and hunting grounds. Most of them regularly submit the eye lenses from first hunts, and then, upon completion of laboratory processing of specimens, they decide whether or not the hunting will continue, and for how long. Due to this fact, we can conclude that stable hare populations exist in over $70 \%$ of hunting grounds in Vojvodina. This strongly suggests that a sustainable management is accomplished and the population will most likely remain stable for years to come if such management practices continue. . 


\section{ACKNOWLEDGMENT}

This paper represents a part of the research results of the Project TR-31084 - financed by the Ministry of Education and Science of the Republic of Serbia within the framework of integrated and interdisciplinary research

\section{REFERENCES}

1. Andersen, J., Jensen, B.: The weight of the eye lens in the European hares of known age. Acta Theriologica, 17, 1-11, 87-92, 1972

2. Cabon-Raczynski, K., Raczynski, J.: Methods for determination of age in the European Hare. Acta theriologica, 17, 1972

3. Černe A., 1976.: Gazdovanje sa populacijama zeca u izmenjenim uvijetima prorodne okoline U: Zbornik radova, Simpozijum o lovstvu, Beograd, 301-302, 1976.

4. Jovanović, V., Aleksić, D,: Prilog poznavanju plodnosti zeca u uslovima Vojvodine. U: Zbornik radova, Simpozijum o lovstvu, Beograd, 281-289, 1976.

5. Lord, R.D.: The lens as an indicator of age in cottontail hares. J. Wildl. Mgmt. 23, 1959

6. Möller, D.,.: Zum Altersaufbau der Hasenpopulationen in der DDR, Betrag zur Jagd. und Wildforschung, IX - Berlin, 1975.

7. Rieck, W.: Analyse von Feldhasenstrecken nach dem Gewicht der Augenlinse. u: Supll. Ricerche di Zoologia appl. alla Caccia, Bologna, vol. IV, 1962

8. Stroch,G..: Zwei sichereAltersmerkmale beim Hasen, Berliner tierarzt. Wschr. 12, Berlin, 1931.

9. Šelmić, V.: Determination of real hunting quotas of brown hare, based on environmental densitz and the real annual growth of population, Phd thesis, Faculty of Forestry, Belgrade, 1977

10. Vapa, L., Dian, M., Obreht, D., Hammer, S., and Suchentrunk, F,: Allozyme variability of brown hares (Lepus europaeus) from the Vojvodina (Serbia), compared to central and southeastern european populations. Acta Zoologica Academiae Scientiarum Hungaricae 53, 1, 75-87, 2007.

11. Valentinčić, S.: Idealni godišnji priraštaj zeca. U: Godišnjak Instituta za naučna istraživanja u lovstvu za 1954, 15-21, Beograd, 1955

12. Valentinčić, S.: $\mathrm{O}$ rezultatima dvogodišnjeg osmatranja i proučavanja divljih zečeva na Bisernom ostrvu. U: Godišnjak Instituta za naučna istraživanja u lovstvu za 1955, 45-60, Beograd, 1956

Primljeno: 20.07.2016.

Odobreno: 15.09.2016. 